\title{
Post Device
}

National Cancer Institute

\section{Source}

National Cancer Institute. Post Device. NCI Thesaurus. Code C50112.

A structural device part that supports or aligns other parts. 